\title{
Valsalva leak point pressure measurement in women with stress urinary incontinence: at what bladder volume?
}

\begin{abstract}
Valsalva leak point pressure (VLPP) is a dynamic test that measures the bladder neck or proximal urethra response to abdominal pressure during the evaluation of stress urinary incontinence (SUI) in women by a urodynamic study (UDS). It is an important urodynamic tool for the assessment of disease severity, choice of therapy and objective post therapeutic follow- up. However, many factors including the bladder volume affect VLPP and therefore a standardization of these factors is still necessary. A number of studies suggest that as the bladder volume increases VLPP decreases, implying that higher bladder volumes open the urethra sphincters henceforth VLPP demonstrated at these bladder volumes might reflect the distal urethra function instead of the proximal urethra function. We hereby highlight the effects of bladder volume on VLPP in women with SUI and recommend the bladder volume at which VLPP should be demonstrated out during the urodynamic assessment of urethra function after reviewing a number of available clinical studies.
\end{abstract}

Keywords: valsalva leak point pressure, Bladder volume, urodynamic study, Stress urinary incontinence
Volume 4 Issue 6 - 2017

\author{
Gallina Kazobinka,' Musa Male, ${ }^{2}$ Dandan Liu,' \\ James Lubuulwa, ${ }^{3}$ Han Xiao Min,' Min Chen' \\ 'Department of Urology, Wuhan Union hospital, China \\ 'Department of Urology, Tongji Hospital, China \\ ${ }^{3}$ Department of Neurosurgery, Tongji Hospital, China
}

Correspondence: Min Chen, Department of Urology, Wuhan Union Hospital,Tongii Medical College, Huazhong University of Science and Technology (HUST), Wuhan 430022, China, Tel 0086-1397|452378, Fax 0086-27-85776343, Email tjmchen@163.com

Received: May 23, 2017 | Published: June 13, 2017
Abbreviations: LPP, leak point pressure; DLPP, detrusor leak point pressure; ALPP, abdominal leak point pressure; SLPP, stress leak point pressure; VLPP, valsalva leak point pressure; CLPP, cough leak point pressure; SUI, stress urinary incontinence; UDS, urodynamic study; ISD: intrinsic sphincter dysfunction; IUS: internal urethral sphincter, EUS, external urethral sphincter; CMG, cystometography; MUCP, maximum urethral closure pressure; UPP, urethral pressure profile

\section{Introduction}

Leak point pressure (LPP) which represents the pressure at which a urinary leak occurs is a highly-favored measurement for the assessment of urethral function. According to the context, LPP can be either Detrusor leak point pressure (DLPP) when evaluating the effect of urethral function on upper urinary tract or abdominal leak point pressure (ALPP) when evaluating urinary incontinence. ALPP can be either Valsalva leak point pressure (VLPP) or Cough leak point pressure (CLPP) depending on the stress maneuver used to generate the pressure. Thus, VLPP also referred to ALPP or stress leak point pressure (SLPP) ${ }^{2}$ is defined as the lowest intravesical pressure, measured at a known bladder volume, at which leakage ${ }^{3}$ occurs during the deliberate increase in abdominal pressure in the absence of a detrusor contraction. That is to say, the pressure inside the bladder at the time when urine is seen leaking out during abdominal straining.

CLPP differs to VLPP in such a way that a cough is the stress maneuver used to raise the abdominal pressure. Nevertheless, cough is thought to have a more mechanical, rather than neuromuscular basis for its dynamics signal ${ }^{4}$ and the spike produced during the urodynamic testing does not accurately describe when the leakage occurred. Because coughing may induce a detrusor contraction therefore, CLPP measurement ${ }^{5}$ is performed when VLPP is negative. Even though, VLPP is the measurement of choice for the diagnosis of stress urinary incontinence (SUI) in women, there is no standardized methodology for its measurement and this lack ${ }^{1,6}$ is unceasingly mentioned. SUI as defined by the international continence society (ICS Abrams $2003)^{7}$ is the complaint of involuntary leakage on effort or exertion, or on sneezing or coughing. It is the most prevalent form of urinary incontinence, ${ }^{8,9}$ with an estimation between $15 \%$ and $55 \%{ }^{10}$ in women complaining of lower urinary tract symptoms (LUTS). Meanwhile, Urodynamic study (UDS) ${ }^{1}$ is simply the use of appropriate methods to study the function and the dysfunction of the urinary tract. It is an effective test to assess the patient's lower urinary tract function and it is advised in women with SUI by many major international organizations ${ }^{11-13}$ especially when an invasive management is to be considered or in the presence of complicating factors. In such patients, urethral storage function and dysfunction can be assessed by measuring urinary VLPP during filling cystometry.

Technically, VLLP is a dynamic test that measures the proximal urethra and bladder neck response to abdominal pressure ${ }^{1}$ and its value allows the clinical classification of SUI [14-16] into urethra hypermobility and intrinsic sphincter deficiency. Originally suggested by McGuire ${ }^{5,17}$ VLPP was used for the assessment of intrinsic sphincter dysfunction (ISD) patients with SUI. The results of his study suggested cut-off values for VLPP to determine the severity of SUI. And that VLPP of less than $60 \mathrm{~cm} \mathrm{H} 2 \mathrm{O}$ correlated with severe grade, VLPP of 60- $90 \mathrm{~cm} \mathrm{H} 2 \mathrm{O}$ with moderate grade, and while that greater than $90 \mathrm{cmH} 2 \mathrm{O}$ correlated with mild grade. These values were subsequently used to classify the types of $\mathrm{SUI}^{1,18}$ as 1 ) anatomical, with VLPP greater than $90 \mathrm{~cm} \mathrm{H2O}$; 2) ISD, with VLPP less than 60 $\mathrm{cm} \mathrm{H2O}$; and 3) a combination of anatomical and ISD, with VLPP between $60-90 \mathrm{~cm} \mathrm{H} 2 \mathrm{O}$.

Basically, VLPP measurement provides disease severity classification, governs the choice of therapy and allows an objective post therapeutic follow up. Despite the fact that VLPP is such an important objective urodynamic tool for the assessment of urethral function many factors [6] such as urethral catheter size, zeroing of the transducer, patient position, type of stress, timing of measurement and bladder volume, affect VLPP value and a standardization of these 
factors is still necessary. The effect of bladder volume on VLPP has been mentioned but little agreement exists on the volume to use during this test as summarized in Table 1. Certain authors described that VLPP decreased progressively ${ }^{19-21}$ as the bladder volume increased during filling in the same patients. In fact, during a VLPP measurement, the total vector force on the urethra includes ${ }^{5}$ the detrusor pressure, the abdominal pressure, for the study and the abdominal viscera. In SUI patients, the rise of abdominal pressure might open the incompetent internal sphincter which leads to urine leakage. While the rise of detrusor pressure triggers the external urethral sphincter, which opens and permits a volitional voiding.

Literally, the urethral $^{22}$ is made of two sphincters. Proximally, the internal urethral sphincter (IUS) under involuntary control consists of smooth muscle and is continuous with the detrusor muscle. It is equivalent to the bladder neck and is prone to descend and be displaced out of the abdominal cavity in case of failure of the normal anatomic support. Loss of bladder neck support is often attributed to nerve, muscle and connective tissue injury and is described as a urethral hypermobility. An IUS with poor periurethral support tissues due to ${ }^{7}$ inadequate estrogen levels, previous vaginal surgery or certain neurologic lesions associated with poor urethral sphincter function is considered as an intrinsic sphincter deficient (ISD). Even though controversies on VLPP measurement in women with SUI remain, VLPP provides a reliable differentiation between these two conditions of the IUS and filling cystometry exclude other associated disease ${ }^{23}$ such as detrusor overactivity in women with SUI. Distally, the external urethral sphincter (EUS) under voluntary control is made up of striated muscle. EUS ${ }^{22}$ also known as the urogenital sphincter acts as a secondary sphincter to control the urine flow through the urethra. Loss of sphincter function in women with $\mathrm{SUI}^{24}$ partially or completely has also been detected using a intraurethral ultrasound (IUUS).

In consideration of the anatomy of the urethral sphincter and its closing mechanism, high bladder volume raises the detrusor pressure which slightly opens the EUS ${ }^{6}$ and thus may demonstrate an incompetent external sphincter instead of demonstrating the internal sphincter function during a VLPP measurement. Likewise, the possibility of high bladder volume rendering ${ }^{25}$ a hypermobile urethra into an intrinsically deficient urethra has been mentioned Thus, we hypothesized that at different bladder volume, VLPP may represent different parts of the urethra continence mechanism and an accurate amount of bladder volume is needed for UDS to carry a proper diagnosis.

\section{Methodology}

We performed a search of clinical studies related to urodynamic assessment of SUI, published in the Medline (Pubmed, Google scholar) using the keywords 'valsalva leak point pressure', 'bladder volume', 'urodynamic study', 'stress urinary incontinence'. Regardless of the publication time, articles published in English and French language were selected. Only original papers reporting clinical studies on women with SUI were reviewed. Among all the urodynamic parameters, only VLPP values and bladder volumes were considered. Data retrieved were tabulated as shown in Table 1. Steven $\mathrm{P}$ does not state a recommended bladder volume because he observed no change in VLPP with the increment of bladder volume. James P. has the highest recommended bladder volume of $300 \mathrm{ml}$. Previously; the recommended bladder volume was reported to be 150$300 \mathrm{ml}$ (1995-1998). But from 2003 to date, the recommended bladder volume range is $200-250 \mathrm{ml}$ as shown in the table above.

\section{Discussion}

In the aforementioned studies, the recommended bladder volume for VLPP measurement ranges between 150-300ml. According to Atlas of Urodynamic,$^{30}$ it is recommended that if leakage does not occur at $150 \mathrm{ml}$, the bladder should be filled and the stress maneuvers repeated until leakage occurs or until bladder capacity is reached. Yet, at bladder capacity, there is risk of detrusor pressure elevation. Among the eight studies, one study did not notice any observable effect of the bladder volume on VLPP, ${ }^{27}$ while five studies ${ }^{3,19-21,25,26}$ described a decreasing VLPP value with increasing bladder volume. This suggests that there is an inverse correlation between VLPP and bladder volume which implies that higher bladder volumes mildly increase the detrusor pressure ${ }^{3}$ which opens the EUS and subsequently results in a low VLPP. In his study, Gary et al. showed that a bladder volume of $250-300 \mathrm{ml}$ correlates best with fluoroscopic findings for an appropriate classification of the patients ${ }^{25}$ with an increased detection of ISD. According to his findings, volumes less than 250 $\mathrm{ml}$ often do not result in leakage. He further explained that at smaller bladder volumes, VLPP is greater than $60 \mathrm{cmH} 2 \mathrm{O}$ in some women with ISD while greater bladder volumes (more than $300 \mathrm{ml}$ ) may result in the incorrect classification of women with anatomical incontinence (type I and II), although all patients with ISD would be appropriately classified at this volume.

Francois Haab et al..$^{20}$ observed the same effect of VLPP decreasing with high bladder volume especially in women with SUI type II and suggested that a bladder volume of $200 \mathrm{ml}$ corresponds to a sensitivity and specificity of more than $80 \%$ in the diagnosis of ISD. Miklos et al. ${ }^{19}$ suggested a bladder volume between $150-250 \mathrm{ml}$ for the measurement of VLPP. He mentioned a significant decrease of VLPP from the bladder volume of $150 \mathrm{ml}$ to $300 \mathrm{ml}$ and between $150 \mathrm{ml}$ and maximum cystometric capacity. Similarly, Young Seo et al. ${ }^{21}$ found a decrease of VLPP at a bladder volume of $250 \mathrm{ml}$ compared to 150 $200 \mathrm{ml}$ and further indicated that a bladder volume of $200 \mathrm{ml}$ for the demonstration of VLPP has $50 \%$ increase in the detection of ISD. On the contrary, Petrou et al. ${ }^{27}$ observed no change in VLPP with the bladder volume and concluded that the volume in the bladder should not affect the VLPP as long as the detrusor pressure is kept at a level that does not affect the urethra.

Meanwhile, Eu Chang wang et al. ${ }^{21}$ reported an excellent intraindividual reproducibility of VLPP at a bladder volume of $250 \mathrm{ml}$. This review therefore highlights different bladder volume used to demonstrate VLPP in various studies and exhibits the effect of the bladder volume on VLPP. Not only VLPP is affected by the bladder volume but it is also affected by the detrusor pressure at some extent. The Cystometography (CMG) can miss about 50\% of cases $^{14}$ of a detrusor contraction-related incontinence and this condition is associated with higher bladder volumes. Higher bladder volumes mildly increase the detrusor pressure which opens the urethra sphincters and VLPP demonstrated at these bladder volumes might reflect the external sphincter function instead of the internal sphincter function.

\section{Conclusion}

Normal urethra should sustain an increased abdominal pressure at any bladder volume by its internal and external sphincter mechanism. Urine leakage during a raised abdominal pressure suggests a pathological urethra. Clearly, the bladder volume affects the intravesical pressure which in turn affects VLPP. Based on the chronologic evolution of the recommended bladder volume (Table 
1) and the evidence provided, a bladder volume of $200-250 \mathrm{ml}$ may express VLPP without elevating detrusor pressure and therefore reflect the internal sphincter function. Furthermore, Maximum urethral closure pressure (MUCP) can also provide additional information about urethra function in women with SUI. ${ }^{21,22}$ Hence, further studies correlating MUCP and VLPP measured at different bladder volume can contribute in the consensus of bladder volume and VLPP measurement. This review focused on the effect of bladder volume on VLPP and attempted to suggest the bladder volume at which VLPP measurement should be considered for the proximal urethra assessment.

Table I Characteristics of included studies

\begin{tabular}{|c|c|c|c|c|c|c|c|c|c|}
\hline Author & $\begin{array}{l}\text { Publication } \\
\text { Year }\end{array}$ & $\begin{array}{l}\text { Number of } \\
\text { Patients }\end{array}$ & $\begin{array}{l}\text { Mean } \\
\text { Age }\end{array}$ & $\begin{array}{l}\text { Bladder } \\
\text { Volume } \\
\text { Used }(\mathrm{ml})\end{array}$ & $\begin{array}{l}\text { Effect of Bladder } \\
\text { Volume on VLPP }\end{array}$ & $\begin{array}{l}\text { Recommended } \\
\text { Bladder Volume } \\
(\mathrm{ml})\end{array}$ & $\begin{array}{l}\text { Type of } \\
\text { UDS }\end{array}$ & $\begin{array}{l}\text { Catheter } \\
\text { Size (Fr) }\end{array}$ & $\begin{array}{l}\text { Patient } \\
\text { Position }\end{array}$ \\
\hline Miklos et al. ${ }^{19}$ & 1995 & 30 & 46.2 & $150,300,400$ & $\begin{array}{l}\text { Decrease with } \\
\text { increasing bladder } \\
\text { volume }\end{array}$ & $150-250$ & Water & 8 & Upright 90 \\
\hline $\begin{array}{l}\text { James P } \\
\text { Theofrastous et al. }{ }^{26}\end{array}$ & 61996 & 120 & $\mathrm{~N} / \mathrm{A}^{* *}$ & $\begin{array}{l}100,200,300 \\
\text { and } \text { MCC* }^{*}\end{array}$ & $\begin{array}{l}\text { Decrease with } \\
\text { increasing bladder } \\
\text { volume }\end{array}$ & 300 & Water & 8 & Upright 45 \\
\hline $\begin{array}{l}\text { Steven P Petrou } \\
\text { et al. }{ }^{27}\end{array}$ & 1998 & 29 & $66 \pm 12$ & $\begin{array}{l}\text { I50, 300, } \\
\text { MCC* }^{*}\end{array}$ & $\begin{array}{l}\text { No change with } \\
\text { bladder volume }\end{array}$ & $N / A^{* *}$ & Fluoroscopic & 10 & Upright 45 \\
\hline $\begin{array}{l}\text { Gary J Faerber et } \\
\text { al. }{ }^{25}\end{array}$ & 1998 & 52 & 52 & 250,300 & $\begin{array}{l}\text { Decrease with } \\
\text { increasing bladder } \\
\text { volume in type } 2 \text { and } \\
3 \text { and Increase with } \\
\text { bladder volume in } \\
\text { type I }\end{array}$ & $250-300$ & Fluoroscopic & 10 & Upright 30 \\
\hline $\begin{array}{l}\text { Francois Haab et } \\
\text { al. }{ }^{20}\end{array}$ & 2003 & 50 & $\mathrm{~N} / \mathrm{A}^{* *}$ & $\begin{array}{l}100,200,300 \\
400\end{array}$ & $\begin{array}{l}\text { Decrease with } \\
\text { increasing bladder } \\
\text { volume }\end{array}$ & 200 & Fluoroscopic & 7 & Standing \\
\hline $\begin{array}{l}\text { Fernando G. } \\
\text { Almeida et al. }{ }^{28}\end{array}$ & 2005 & 200 & $\mathrm{~N} / \mathrm{A}^{* *}$ & $50,200,250$ & $\begin{array}{l}\text { Remarkable } \\
\text { correlation of VLPP } \\
\text { and UPP at } 200 \mathrm{ml}\end{array}$ & 200 & $\mathrm{~N} / \mathrm{A}^{* *}$ & 7 & $\mathrm{~N} / \mathrm{A}^{* *}$ \\
\hline $\begin{array}{l}\text { Young Ho Seo et } \\
\text { al. }^{21}\end{array}$ & 2016 & 228 & $51.3 \pm 7.6$ & $\begin{array}{l}150,200,250, \\
300\end{array}$ & $\begin{array}{l}\text { Decrease with } \\
\text { increasing bladder } \\
\text { volume }\end{array}$ & 200 & water & 8 & Lithotomy \\
\hline $\begin{array}{l}\text { Eu Chang Hwang } \\
\text { et al. }{ }^{29}\end{array}$ & 2016 & 65 & $51.5 \pm 7.9$ & 250 & $\begin{array}{l}\text { Excellent } \\
\text { intraindividual } \\
\text { reproducibility }\end{array}$ & 250 & Water & 8 & Lithotomy \\
\hline
\end{tabular}

Capacity

**N/A: Not available

Note: *MCC: Maximum Cystometric

\section{Acknowledgments}

None.

\section{Conflicts of Interset}

None.

\section{References}

1. Burden H, Warren K, Abrams P. Leak point pressures: how useful are they? Curr Opin Urol. 2005;25(4):317-322.

2. Swift SE, Ostergard DR. Evaluation of current urodynamic testing methods in the diagnosis of genuine stress incontinence. Obstet Gynecol. 1995;86(1):85-91.

3. Petrou SP, Wan J. VLPP in the evaluation of the female with stress urinary incontinence. Int Urogynecol $J$ Pelvic Floor Dysfunct. 1999;10(4):254-259.

4. Kim K, Jurnalov CD, Ham S, et al. Mechanisms of female urinary continence under stress: frequency spectrum analysis. $J$ Biomech.
2001;34(5):687-691.

5. McGuire EJ, Cespedes RD, O'Connell HE. Leak-point pressures. Urol Clin North Am. 1996;23(2):253-262.

6. Daneshgari F. Valsalva leak point pressure: steps toward standardization. Curr Urol Rep. 2001;2(5):388-391.

7. Walton T. Female urinary incontinence. Female Urology-Incontinence. 2010.

8. Lu S, Zhang HL, Zhang YJ, et al. Prevalence and risk factors of urinary incontinence among perimenopausal women in Wuhan. J Huazhong Univ Sci Technolog Med Sci. 2016;36(5):723-726.

9. Syan R, Brucker BM. Guideline of guidelines: urinary incontinence. BJU International. 2015;117: 20-33.

10. Mota RL. Female urinary incontinence and sexuality. Int Braz J Urol. 2017;43(1):20-28.

11. ICS, ICS FACTS SHEET. ICS news, 2015.

12. Lucas MG, Bedretdinova D, Berghmans LC, et al. Guidelines on Urinary Incontinence. European Association of Urology 2015. p. 13-14. 
13. Winters JC, Dmochowski RR, Goldman HB, et al. ADULT URODYNAMICS: AUA/SUFU GUIDELINE. American Urological Association. 2012.

14. Kalejaiye O, Vij M, Drake MJ. Classification of stress urinary incontinence. World J Urol. 2015;33(9):1215-1220.

15. Huang IS, Fan YH, Lin AT, et al. Correlation between Bladder Neck Mobility and Voiding Phase Urodynamic Parameters in Female Patients with Stress Urinary Incontinence. Low Urin Tract Symptoms. 2016;8(1):44-48.

16. Macura KJ, Thompson RE, Bluemke DA, et al. Magnetic resonance imaging in assessment of stress urinary incontinence in women: Parameters differentiating urethral hypermobility and intrinsic sphincter deficiency. World J Radiol. 2015;7(11):394-404.

17. McGuire EJ, Woodside JR, Borden TA, et al. Prognostic value of urodynamic testing in myelodysplastic patients. $J$ Urol. 1981;126(2):205-209.

18. Kim HG, Park HK, Paick SH, et al. Comparison of Effectiveness between Tension-Free Vaginal Tape (TVT) and Trans-Obturator Tape (TOT) in Patients with Stress Urinary Incontinence and Intrinsic Sphincter Deficiency. PLoS One. 2016;11(5):e0156306.

19. Miklos JR, Sze EH, Karram MM. A critical appraisal of the methods of measuring leak-point pressures in women with stress incontinence. Obstet Gynecol. 1995;86(3):349-352.

20. Haab F, Dmochowski R, Zimmern P, et al. The variability of the leakage pressure threshold due to exertion "the Valsalva Leak Point Pressure" as a function of the filling volume of the bladder. Prog Urol. 1997;7(3):422-425
21. Seo YH, Kim SO, Yu HS, et al. Leak point pressure at different bladder volumes in stress urinary incontinence in women: Comparison between Valsalva and cough-induced leak point pressure. Can Urol Assoc J. 2016;10(1-2): E23-E27.

22. Jung J, Ahn HK, Huh Y. Clinical and functional anatomy of the urethral sphincter. Int Neurourol J. 2016;16(3):102-106.

23. Valdevenito JP, Águilaa F, Naserb M, et al. Urodynamic study in women with pure stress urinary incontinence. Actas Urol Esp. 2015;39(2):98-103

24. Frauscher F, Helweg G, Strasser H, et al. Intraurethral ultrasound: diagnostic evaluation of the striated urethral sphincter in incontinent females. Eur Radiol. 1998;8(1):50-53.

25. Faerber GJ, Vashi AR. Variations in Valsalva leak point pressure with increasing vesical volume. J Urol. 1998;159(6):1909-1911.

26. Theofrastous JP. The effect of vesical volume on Valsalva leak-point pressures in women with genuine stress urinary incontinence. Obstet Gynecol. 1996;87(5 Pt 1):711-714.

27. Petrou SP, Kollmorgen TA. Valsalva leak point pressure and bladder volume. Neurourol Urodyn. 1998;17(1): 3-7.

28. Almeida FG, Bruschini H, Srougi M. Correlation between urethral sphincter activity and Valsalva leak point pressure at different bladder distentions: revisiting the urethral pressure profile. $J$ Urol. 2005;174(4 Pt 1):1312-1315; discussion 1315-1316.

29. Hwang EC, Kim SO, Kwon DD. Reproducibility of Leak Point Pressure in Female Stress Urinary Incontinence. Urol J. 2016;13(3):2697-701.

30. Blaivas JG, Chancellor M, Weiss J, et al. Atlas of Urodynamics. Lippincott Williams \& Wilkins, USA. 2007. 